\title{
PENGEMBANGAN KAJIAN KEARIFAN LOKAL DALAM PENDIDIKAN UNTUK PENINGKATAN KUALITAS SUMBERDAYA MANUSIA
}

\section{S.H. Maelissa}

\section{PENDAHULUAN}

Untuk memudahkan refleksi persoalan dari judul di atas maka diberikan pengertian etimologis sebagai berikut :

- Kaji berarti belajar, mempelajari, menyelidiki, memikirkan dan mempertimbangkan (Purwadarminta 1976:433).

- Arif artinya mengetahui atau orang yang tahu segala hal, juga diartikan cerdik pandai, bijaksana atau berilmu (Purwadarminta 1976:57).

- Pengembangan kajian Kearifan Lokal dimaksudkan sebagai upaya untuk mempelajari atau menyelidiki segala hal yang berhubungan dengan kebijaksanaan dalam pengembangan budaya orang-orang Maluku untuk diwariskan melalui pendidikan formal maupun informal. Didalam nilai-nilai tradisional terdapat kearifan-kearifan lokal (Local Wisdom) yang perlu dijaga dan dipelihara karena mengandung nilai-nilai universal dan sangat berharga apabila dikembangkan dan diaktualisasikan.

Kita menyadari bahwa masyarakat dunia yang terkotak-kotak secara tegas oleh tembok-tembok negara, politik, ekonomi, budaya, maupun ilmu pengetahuan dan teknologi, kini mulai runtuh dan terhayut oleh perubahan karena gelombang globalisasi. Ruang dan waktu menjadi sangat relatif dan dalam banyak hal batas-batas negara sering menjadi kabur dan tidak relevan. Hal ini dapat disaksikan dengan jelas kejadian-kejadian di sebahagian besar dunia dengan selisih waktu yang sangat tipis. Dalam momen yang sama kita dengan masyarakat lain di dunia dapat menyaksikan pertandingan sepak bola antara MU (Manchester United) dengan kesebelasan Liverpool di Roma. Kita dapat melihat dan mendengar dengan jelas perdebatan antara kandidat-kandidat Presiden USA dari partai Demokrat, Hillary Clinton dengan Obama dalam waktu yang hampir sama dengan masyarakat 
Amerika. Kita mengenal dengan mudah dunia lain mengenai sistem sosial, sistem budaya, sistem politik, sistem ekonomi, organisasi, tingkah laku individu dan kehidupan individu yang rahasia pun dapat diketahui. Dunia menjadi semakin kecil karena revolusi informasi. Kehidupan dunia menjadi transparan. Sifat transparan ini tidak menutup kemungkinan terciptanya nilai dan norma yang sama bagi seluruh dunia.

Dunia Timur atau negara-negara berkembang termasuk Indonesia merasa dilanda atau harus menerima nilai-nilai baru untuk berperan secara aktif dalam masyarakat dunia. Dengan demikian apakah kita ingin menjadi manusia dunia atau manusia yang berperan di dunia dengan identitas tersendiri? Bila yang terakhir kita inginkan berarti kebudayaan Nasional Indonesia bukan saja harus berakar pada nilai-nilai luhur kebudayaannya sendiri termasuk budaya-budaya lokal yang patut dilestarikan. Salah satu upaya untuk itu adalah melalui pembinaan dan pengembangan kearifan lokal yang mampu menyesuaikan diri dengan pengembangan ilmu pengetahuan dan teknologi sehingga dapat mempertahankan diri dan berdiri teguh di tengah-tengah kebudayaan bangsa dan dunia.

Tylor mengatakan kebudayaan adalah keseluruhan kompleks yang termasuk didalamnya pengetahuan, kepercayaan, seni, moral, hukum, adat dan segala macam kemampuan dan kebiasaan yang didapat oleh masyarakat. G. Naegel menyatakan bahwa kebudayaan adalah istilah kolektif untuk polapola keberadaan dan pernyataan normatif. Pernyataan-pernyataan normatif itu dapat berupa kata-kata dalam literatur, bahasa atau drama, berupa suara dalam musik, simbol-simbol dari seni patung, gerakan dalam tarian, gaya dalam pakaian dan sebagainya (George Allen, 1972:55). Arief Rachman yang mengutip Linton menyatakan bahwa budaya adalah keseluruhan dari pengetahuan, sikap dan pola perilaku yang merupakan kebiasaan yang dimiliki dan diwariskan oleh anggota suatu masyarakat tertentu (Arief Rachman, 2005:3). Bertolak dari ketiga pengertian kebudayaan di atas dapat dirumuskan budaya Maluku sebagai keseluruhan nilai (hal-hal yang berharga) yang dipelihara, dikembangkan dan diwariskan dalam masyarakat Maluku.

\section{BENTUK-BENTUK KEARIFAN LOKAL}

Masing-masing suku bangsa membangun dan mengembangkan kebudayaannya melalui pelbagai pengalaman sejarah yang dimiliki, melalui kemampuan adaptasi dengan lingkungan dan melalui pengetahuan yang datang dari dalam dirinya sendiri. Tidak dapat disangkal bahwa kebudayaan lokal berkembang dari waktu ke waktu sesuai perkembangan zaman. Adaptasi kebudayaan dari suatu suku bangsa terhadap kebudayaan suku bangsa yang lain atau penerimaan sebuah nilai baru yang dianggap berguna dan menguntungkan karena sesuai dengan kebutuhan masyarakat pendukung kebudayaan memberikan nuansa baru kepada kebudayannya, kemudian diterima sebagai kebudayaan sendiri. Hasil akulturasi kebudayaan ini sudah lama terjadi disepanjang sejarah suku bangsa di Nusantara ini. Kebudayaan Hindu dan Islam, kemudian kebudayaan bangsa-bangsa lain seperti Portugis, Spanyol dan Belanda juga berpengaruh terhadap kebudayaan asli. Di Kepulauan Maluku, pengaruh dari kebudayaan Melayu dan Polynesia serta Melanesia juga memberi warna terhadap kebudayaankebudayaan suku bangsa yang ada di daerah ini. Kebudayaan suku bangsa ini mempunyai nilai-nilai tersendiri yang dipatuhi sebagai nilai mutlak yang sukar ditiadakan dalam kehidupannya. Mangabaikan nilai mutlak ini dianggap sebagai pengkhianatan terhadap kebudayaan suku bangsa tersebut. Nilai mutlak dipuja sebagai yang terbaik bila dibanding dengan nilai mutlak dari suku bangsa lain yang tercermin dari perilaku pendukung kebudayaan suku bangsa. Kebudayaan suku bangsa ini dipelihara dengan baik melalui sosialisasi di lingkungan keluarga terutama generasi muda.

Kearifan lokal Maluku berkembang dari suatu akar budaya tertentu. Dari sudut pandang historis akar budaya adalah budaya yang terdapat pada saat terbentuknya suatu masyarakat. Sementara dari perspektif sosiologis akar budaya berarti nilai yang terdapat pada suatu masyarakat yang membentuk kepribadian awal. Dengan demikian akar budaya harus dicari pada kelompok-kelompok masyarakat pertama yang membentuk kepribadian awal di Maluku.

Ketika manusia Maluku berpindah dari pegunungan ke dataran rendah dekat pesisir pantai, merekapun menetap dan membentuk keluarga batih yang disebut Rumatau (Maluku Tengah) atau Raham Jan (Maluku Tenggara) dan Belang (Aru). Kelompok ini yang merupakan basis dari 
hubungan-hubungan sosial. Beberapa Rumatau atau Raham Jan yang berdekatan membentuk Aman atau Hena (Maluku Tengah), Oboi (Maluku Tenggara) yaitu satuan pemukiman masa awal. Beberapa satuan pemukiman yang mendiami suatu daerah tertentu disebut Uli/Pata (Maluku Tengah) atau Ur (Maluku Tenggara).

Manusia Maluku yang sudah menetap itu telah mempunyai pandangan terhadap dunia (world view) yaitu dunia atas dan dunia bawah sebagai suatu kesatuan yang tidak dapat dipisahkan. Pandangan dunia tersebut terpantul pada cara memandang masyarakat sebagai isi dunia. Kedua Uli/Ur tersebut merupakan suatu kesatuan yang tidak dapat dipisahkan. Siwa Lima (sembilan-lima) mempunyai budaya yang sama dengan perbedaan variasi tertentu. Oleh karena itu budaya Siwalima bersifat monodualistis dengan nilai persatuan dan persaudaraan. Dengan begitu persatuan dan persaudaraan masyarakat merupakan kepribadian dan akar budaya Maluku. Diatas nilai persatuan dan persaudaraan itulah dikembangkan kearifankearifan lokal yang bermakna.

Bentuk-bentuk kearifan lokal seperti apa yang perlu dilestarikan dan dibina terus agar tidak punah diterpa badai globalisasi?

1. Sistem Pela dan Gandong di Ambon / Maluku Tengah.

Teabel di Kei

Kida bela di Tanimbar

Jabu di Aru

2. Masohi di Maluku Tengah.

Mareu (Hamareu) dan Weer Warat di Kei

Simasale di Tanimbar

Nekohora di Babar

Teren di Kisar

3. Sasi di Maluku Tengah

Hawear di Maluku Tenggara

Hawer di Kepulauan Aru

4. Pemerintahan adat

5. Aspek Seni Budaya

1. Pela dan Gandong

Sistem Pela dan Gandong merupakan ikatan persahabatan atau persaudaraan yang diaktualisasikan dalam sapaan-sapaan kekerabatan seperti
Nyong Pee, Nona Pela, Gandonge, Bongsoee, maupun aktifitas tolong menolong dalam keadaan aman maupun kesusahan. Larangan dan kewajiban di antara warga yang ber-pela dan gandong atau Bongso itu dipelihara dan ditaati dengan penuh tanggung jawab, didasari adanya penghormatan atas janji dan sumpah leluhur yang telah mengikat dirinya, keluarganya bahkan juga negerinya. Pada waktu-waktu tertentu ada upacara panas pela / gandong yaitu upacara adat yang bermakna untuk terus menghidupkan ingatan-ingatan kebersamaan diantara mereka.

Perserikatan Kida Bela di kepulauan Tanimbar bermakna hampir sama dengan pela. Kida Bela sanggup membuat orang untuk tidak berkelahi, tidak bercerai-berai atau membuat tindakan-tindakan lain yang mengakibatkan keresahan dalam masyarakat. Pada waktu-waktu tertentu diselenggarakan upacara Fangla Kida Bela untuk mengingatkan kembali peristiwa sejarah itu. Selain itu ada pula yang disebut Yaan warin Rinun yaitu ikatan yang terjadi diantara individu atau antar warga desa, dilatarbelakangi oleh peristiwa tolong menolong (bencana alam, paceklik). Hubungan yang terjadi atas dasar tali kekeluargaan ini sanggup membuat semua orang di dalamnya hidup rukun dengan prinsip tolong-menolong. Masyarakat Kei mengenal apa yang disebut ikatan Tea Belyakni ikatan perjanjian persahabatan diantara kampung dimana ikatan perjanjian itupun dilakukan dengan darah. Tea artinya menggores, Bel artinya darah mengalir.

Di Kepulauan Aru disebut Bela atau Jabu. Makna kemanusiaan dari semua bentuk ikatan kekerabatan itu adalah tolong-menolong, tenggang rasa, saling percaya dan bersaudara. Hubungan-hubungan persaudaraan dan persahabatan itu masih diakui oleh pendukungnya bahkan setelah konflik selesai masyarakat adat giat merespon hubungan-hubungan itu kembali dalam bentuk upacara Panas Pela, pelantikan Raja, silaturrahmi negeri-negeri Pela dan Gandong. Pranata tradisional yang mengandung nilai-nilai kemanusiaan itu hendaknya tidak diberikan makna pada hubungan kekerabatan antar orang Basudara saja yang memberi ciri identitas kebudayaan lokal, nilai esensi kebudayaan lokal itu dapat disosialisasikan kepada orang lain. Dengan demikian akan terpelihara hidup rukun, harmonis penuh toleransi antar sesama bahkan saat berjumpa dengan pendukung budaya lain dengan dasar salimg menghormati dan menghargai. 
2. Masobi, Maren dan Weer Warat, Simasale Nekohoro dan Teren

Masobi, Maren dan Weer Warat, Simasale Nekohoro dan Teren adalah sistem tolong-menolong didalam melaksanakan kepentingan seseorang. Dalam perkembangnya nilai tolong-menolong mengalami degradasi karena masuknya ekonomi uang. Kondisi ini berdampak pada menurunnya aktifitas berkumpul bersama sehingga merenggangkan kebiasaan saling bertemu keluarga yang dilakukan di desa.

Selain Masobi adapula Badati, Maano, makan Pasuri yang dilakukan sehubungan dengan kepentingan ekonomi seseorang atau orang banyak. Maano adalah sistem bagi hasil (misalnya Cengkeh, pala dan sagu) oleh karena si pemilik kekurangan tenaga untuk memetik hasil maka dapat meminta anggota masyarakat lain untuk memetik dengan imbalan dari hasil yang dipetik sesuai kesepakatan. Badati yaitu sistem tanggung bersama. Sebuah kegiatan yang dilakukan oleh seseorang. Sedangkan makan Pasuri yakni menikmati hasil-hasil kebun, hasil hutan secara bersama-sama oleh warga negeri yang memiliki ikatan sejarah atau kekeluargaan.

Orang-orang Babar di pulau Marsela mengenal Lolya Yi sistem tolong menolong melalui pertukaran hasil kebun atau hasil laut (barter hasil) diantara anggota keluarga walaupun tidak sekampung. Di Kei ada Koi Maduan yang bertujuan untuk saling membantu karena ada kewajiban dan ikatan khusus.

Semua pranata yang bermakna pengerahan tenaga dan aktifitas ekonomi di atas masih terus dilaksanakan oleh masyarakat pedesaan, walaupun ada pula yang telah mengalami degradasi. Patut diakui pranatapranata sosial ini bermanfaat bagi kehidupan masyarakat sehingga nilai yang ada di dalamnya terus dikembangkan. Badati atau Maano mungkin saja dikembangkan dalam bentuk koperasi desa, Joint Venture dan lain sebagainya yang dapat membuka lapangan kerja bagi orang banyak. Aktifitas bermain arisan (uang dan barang) sesungguhnya adalah bentuk Badati masyarakat modern, cukup bermanfaat dan menjalin hubungan persahabatan.

\section{Sasi, Hawear, Hawer}

Dalam menjamin ketertiban sosial serta pelestarian terhadap sumber-sumber hayati dan nabati ada kearifan tradisional yang diartikan dalam simbol-simbol khusus sebagai tanda larangan. Bila melihat daun kelapa yang diikat pada tempat-tempat tertentu maka itu artinya ada Sasi (di Maluku Tengah) yang maknanya adalah larangan bagi anak negeri dan orang luar untuk mengambil sesuatu yang berkaitan dengan sumber-sumber alam. Untuk menjaga ketertiban pelaksanaan Sasi ada Kewang- sampai saat ini Sasi masih dilaksanakan dengan variasi (Sasi Gereja, Sasi Negeri). Sasi dihubungkan dengan musim larangan memetik buah-buah tertentu di darat dan mengambil hasil laut selama waktu tertentu yang ditetapkan oleh pemerintah negeri.

Jenis-jenis yang disasikan meliputi buah-buahan, kacang-kacangan dan ikan-ikan serta hasil laut lain yang menjadi bahan makanan. Sasi merupakan tindakan perlindungan agar persediaan bahan makanan untuk negeri cukup terjamin, yang didasarkan pada pengertian tertentu tentang proses kelanjutan keturunan makluk hidup di laut dan siklus pertumbuhan/ pembuahan di darat.

Terdapat 2 bentuk sasi yang masih ditemukan di daerah Maluku Tengah. Yang pertama adalah bentuk aslinya yang di sebut sasi kewang, berarti larangan yang dilaksanakan oleh petugas-petugas keamanan negeri yaitu kewang. Dalam bentuk yang tradisional, kewang, tua-tua adat, tuan tanah dan kewang negeri mengadakan pertemuan di Baileo pada malam hari untuk membicarakan secara terperinci larangan yang oleh kewang diputuskan perlu dikenakan.

Di Kei ada larangan yang di sebut hawear yang juga memiliki simbol daun kelapa (janur kuning). Di Kepulauan Aru disebut hawer yang maknanya melindungi hak milik seseorang atau sebagai alat mencegah perselisihan antara masyarakat. Keterbatasan aparat penegak hukum sesungguhnya dapat ditanggulangi dengan melibatkan perangkat adat. Karena itu perlu dilakukan penataan kembali berbagai kearifan lokal yang bernilai global beserta perangkat adat sebagai mitra pemerintah yang dibekali dengan payung hukum.

\section{Pemerintah Adat}

Keberadaan pemerintah adat adalah penting untuk menjamin kelangsungan hidup masyarakat adat, bila tidak mau kehilangan identitas diri. Walau namanya berbeda-beda namun persekutuan masyarakt adat yang terakomodir dalam struktur pemerintahan adat harus difungsikan 
kembali. Kehidupan berdemokrasi yang merupakan ciri masyarakat modern sesungguhnya telah dipraktekkan dalam struktur pemerintahan adat. Baileu adalah lambang demokrasi, saniri atau perangkat pejabat adat adalah wujud pembagian kekuasaan demi menghindari penyalahgunaan wewenang dan tindakan otoriter. Semua itu mampu membuat orang Maluku hidup rukun dan mampu melawan berbagai bentuk kelaliman. Bila ada konflik di antara sesama atau antara Negeri maka dapat diselesaikan dengan cepat.

\section{Aspek Seni Budaya}

Seni Budaya mempunyai peran penting dalam pembentukan karakter manusia. Pemahaman perasaan dan ekspresi rasa indah turut membentuk kehalusan budi luhur seseorang menjauhi bentuk-bentuk kekerasan. Tumbuhnya rasa memiliki serta kebanggaan terhadap seni budayanya sendiri akan merupakan senjata yang ampuh untuk menumbuhkan ketahanan budaya serta ketahanan lokal dan nasional menghadapi terpaan angin budaya luar yang negatif. Seni budaya tradisional yang masuk katagori kearifan lokal antara lain :

a. Musik lokal : Musik Lokal tradisional di Maluku Tengah seperti Kapata, Subat, Basaro, Lagu-Lagu Tanah.

b. Musik Instrumental yang perlu dikembangkan adalah :

- Musik Tiup seperti Suling Bamboe, Musik Kulit Bia

- Musik Tabu seperti Tifa dan Totobuang

- Musik gesek seperti musik gesek dari batok kelapa di Kei

c. Seni Tari Tradisional

Orang-orang di Kepulauan Kei memiliki Tari Pana dan Tari Kipas. Orang di Tanimbar memiliki Tari Tnabar Ilaa dan Tari Seka di pulau Kisar. Orang-orang di Maluku Tengah memiliki Tari Cakalele dan Tari Lenso. Tari Hadrat di Ambon dan Tari Sawat di Tulehu.

d. Seni Sastra Trasidisional misalnya pantun dalam badendang dan lain-lain.

e. Teknologi Tradisional yang dikembangkan masyarakat adalah pembuatan perahu, pembuatan jaring penangkap ikan, penangkap binatang buruan (dadeso)

Penciptaan benda-benda kebutuhan kehidupan sehari-hari dengan teknologi tradisional yang bernilai artistik yang disebut produk kriya seperti kain tenun Tanimbar, produk-produk dari tanah liat di Kei, negeri Ouw di Saparua, Perahu Cengkeh, Perhiasan dan lain-lain dari Kulit Mutiara dan Kulit Penyu di Batu Merah

\section{PENGEMBANGAN KEARIFAN LOKAL MELALUI PENDIDIKAN}

Strategi pembinaan dan pengembangan kearifan daerah Maluku perlu dirancang dengan tepat. Selama ini kurikulum muatan lokal yang diberikan di sekolah kurang mengacu pada penanaman nilai-nilai budaya, demikian pula dengan strategi pembelajaran sejarah lokal dalam rangka pembinaan kesadaran sejarah daerah Maluku. Pengetahuan generasi muda tentang budaya lokal, kearifan lokal, aspek-aspek kesejarahan daerah sangat minim, padahal aspek-aspek itu memuat unsur-unsur pemersatu. Untuk itu perlu dilaksanakan gerakan Budaya melalui jalur pendidikan formal dengan memperkenalkan kebudayaan lokal pada masing-masing daerah di Propinsi Maluku, dari tingkat sekolah dasar sampai dengan perguruan tinggi termasuk aspek-aspek sejarah lokal.

Mata pelajaran muatan lokal (Mulok) kini dimasukan dalam sistim pendidikan nasional dan diajarkan pada jenjang Pendidikan Dasar sesuai yang tersirat dalam Pasal 37 dan 38, UU No 2 tahun 1989 tentang sistim Pendidikan Nasional yang mengatakan :

"Kurikulum disusun untuk mewujudkan tujuan Pendidikan Nasional dengan memperhatikan perkembangan peserta didik dan kesesuaiannya dengan lingkungan, kebutuhan pendidikan nasional, perkembangan ilmu dan teknologi serta kesenian, sesuai dengan jenis dan jenjang masing-masing satuan pendidikan. Pelaksanaan dalam satuan pendidikan berdasarkan atas kurikulum yang berlaku secara nasional dan kurikulum yang disesuaikan dengan keadaan serta kebutuhan lingkungan dan ciri khas satuan pendidikan yang bersangkutan."

Selanjutnya ditegaskan dalam Peraturan Pemerintah No. 28 tahun 1990, Pasal 14 ayat 3,4, bahwa :

"Satuan Pendidikan Dasar dapat menambah Mata Pelajaran sesuai dengan keadaan lingkungan dan ciri khas Satuan Pendidikan yang bersangkutan dengan tidak mengurangi kurikulum yang berlaku secara nasional dan tidak menyimpang dari tujuan Pendidikan 
Nasional. Satuan Pendidikan Dasar dapat menjabarkan dan menambah bahan kajian dari Mata Pelajaran sesuai dengan kebutuhan setempat."

Untuk itu dibentuk tim perekayasa kurikulum yang bertugas mengidentifikasi materi muatan lokal. Materi disusun berdasar pada data lapangan dan masukan dari Bapeda dan instansi terkait di tingkat Kabupaten, Kota dan Kecamatan.

Hasil identifikasi ini dikemas sebagai berikut :

"Bahan kajian Budaya Daerah yang dikembangkan dalam kurikulum Muatan Lokal berfungsi untuk mengangkat, menumbuhkembangkan, dan melestarikan nilai-nilai budaya warisan leluhur bangsa. Tujuan diajarkan budaya daerah agar peserta didik dapat memiliki pengetahuan dan sikap mencintai dan menghargai nilai budaya daerah serta mengembangkannya dalam kehidupan sehari-hari.”

a. Ruang Lingkup Sekolah Dasar :

1. Adat istiadat:

$$
\begin{aligned}
& \text { - Pela, Gandong } \\
& \text { - Masohi } \\
& \text { - Sasi-Kewang } \\
& \text { - Upacara adat } \\
& \text { - Seni musik } \\
& \text { - Seni Tari } \\
& \text { - Lagu-lagu Daerah }
\end{aligned}
$$$$
\text { 2. Kesenian Daerah : - Seni musik }
$$

3. Permainan Daerah

b. Ruang Lingkup Muatan Lokal (Mulok) untuk SLTP, meliputi :

1. Adat istiadat : - Pela, Gandong

- Masohi

- Sasi-Kewang

- Adat Perkawinan

2. Kesenian Daerah/Musik Daerah:

- Lagu-Lagu Daerah

- Instrumen Musik Daerah

- Tarian Tradisional Daerah

- Permainan Daerah
Mata Pelajaran Muatan Lokal (Mulok)

Budaya Daerah yang diajarkan pada jenjang Pendidikan Dasar merupakan salah satu upaya pemerintah dalam rangka melestarikan nilainilai budaya dan kearifan lokal sebagai bagian dari Budaya Nasional untuk dikembangkan dan dibina terus, namun masih kurang tenaga profesional mata pelajaran Muatan Lokal (Mulok) dan terbatasnya sumber bahan pelajaran merupakan hambatan utama dalam mengajarkan mata pelajaran ini.

Manusia lahir tanpa membawa budaya. Karena itu budaya berupa idea/ pemikiran, bentuk-bentuk sosial maupun benda yang berada dalam masyarakat termasuk teknologi dan kearifan-kearifan lain perlu diwariskan pada anggota masyarakat yang baru untuk pengaturan sikap dan perilaku, untuk pengetahuan dan penggunaannya dalam kehidupan sosial. Tanpa pewarisan budaya akan terbentuk suatu masyarakat Maluku yang hidup tanpa nilai dan norma, tanpa memahami dan mengaplikasikan fungsi pranata-pranata sosial, ketidakmampuan memaknai simbol-simbol dan tidak sanggup manguasai teknologi. Dengan ini masyarakat Maluku akan menjadi anomali, tidak normal yaitu hidup tanpa kewibawaan hukum dan disorganisasi serta disharmonisasi hubungan antar sesama warga dan sesama umat manusia. Pendidikan untuk pewarisan dimaksudkan untuk internalisasi nilai dan norma sosial, pengetahuan dan pemahaman dan pranata-pranata sosial yang merupakan kearifan lokal serta fungsi benda-benda budaya yang ada dalam masyarakat Maluku. Pewarisan budaya melalui pendidikan supaya dilakukan sejak dini dalam keluarga dan kemudian dilanjutkan dalam pendidikan formal di sekolah dan jalur luar sekolah.

\section{PENUTUP}

Dimensi kemanusiaan yang tercermin dalam pranata-pranata sosial budaya yang dibangun berdasarkan kearifan lokal, dalam berbagai hal telah memberi nilai tambah bagi peningkatan kualitas sumber daya manusia. Pengaturan hubungan sosial dan pelestarian lingkungan akan membawa peningkatan kerjasama dan kesejahteraan sosial terutama peningkatan pendapatan anggota masyarakat.

Di dalam kearifan lokal ada jaringan-jaringan sosial dimana saling percaya merupakan inti dari interaksi individu-individu yang mendukung 
tujuan bersama. Yang dimaksud dengan tujuan bersama ini adalah harapan yang mengandung Sistim Nilai yang berpotensi membawa masyarakat kepada sesuatu yang mendamaikan dan mensejahterakan.

Oleh karena itu untuk mengembangkan sistim nilai budaya dan kearifan lokal diperlukan upaya-upaya pelestariaan melalui media pendidikan formal, informal maupun nonformal. Dan bila hal ini terwujud maka masyarakat Maluku akan menjadi suatu masyarakat yang berkembang, yang berakar pada sistim Nilai Budaya atau suatu masyarakat Maluku yang Baru tanpa menghilangkan identitasnya.

\section{DAFTAR PUSTAKA}

Andaya Leonard, 1993, The World of Maluku, Honolulu, University of Hawaii Press.

Bartel, Dieter, 1977, Guarding the Invisible Mountain: Intervillage Alliances, Religions Syncretism and Ethnic Identity Among Ambonese Christian and Moslems in The Moluccas, PhD. Thesis Cornell University.

Burke Peter, 1980, Sociologi and History, London, George Allen and Unwin.

Car, E.H., 1990, What is History, Penguin Books, Rev. Ed.

Cooley F.L., 1962, Ambonese Adat : A General Description, Yale University, Southeast Asia Studies, New Haven Com.

Depdikbud, 1991, Pengendalian Sosial di Bidang Pelestarian Lingkungan Alam (Kewang) Daerah Maluku, Proyek IPNB.

1992, Pola Penguasaan Pemilikan dan Penggunaan Tanah Secara Tradisional, Proyek P3NB, Maluku.

Effendi, L, 1987, Hukum Adat Ambon Lease, Jakarta, Pradnya Paramitha.

Koentjaraningrat, 1981, Kebudayaan Mentalitas dan Pembangunan, Jakarta, Gramedia.

1990, Manusia dan Kebudayaan di Indonesia, Jakarta, Penerbit

Djambatan.

Leirissa, R.Z., 1982, Maluku Tengah di Masa Lampau, Gambaran Sekilas Lewat Arsip Abad XIX, Jakarta ANRI. 